\title{
A Case Study Of The Cash Flow Statement: US GAAP Conversion To IFRS
}

\author{
Peter Harris, New York Institute of Technology, USA
}

\begin{abstract}
International Reporting Standards (IFRS) has become the required framework for most of the world financial markets effective on January 1, 2011. The United States is in a transformation stage, and it has not yet been determined when the US will adopt IFRS. The introduction of IFRS accounting rules into the curriculum is valuable because it presents an alternative method of accounting which can be used to heighten students understanding of GAAP. At present, the CPA Uniform CPA exam is testing IFRS and its testing content is increasing with each current test. Additionally, the CFA exam tests IFRS exclusively and has eliminated US GAAP from its curriculum, basing its action on the fact that the CFA examination is a global based exam. This case requires students to prepare an IFRS cash Flow Statement from a presented US GAAP presented Statement of Cash Flow, from a given set of facts in the case. This case study can be used at the undergraduate or graduate level. It is most suitable for Intermediate Accounting 2, Accounting Theory, Financial Statement Analysis, and an Accounting Capstone classes. Students must have or develop a solid understanding of both US GAAP and IFRS rules is required to adequately address this cash flow case study.
\end{abstract}

Keywords: US GAAP; IFRS; LIFO; Statement of Cash Flows

\section{COMPANY BACKGROUND}

AXE Corp, a publically traded NASDAQ company (symbol JAL), is a manufacturer of cabinets. Its main headquarters is based in Miami, Florida and the company has been operating since 1981. The company sells its products on the worldwide retail market. The primary compound in JAL's leading products is found only in the rainforests of Central America. Its major customer is Wal-Mart. Its stock sells at 45 US dollars per share, and its 52 week price range is between 37.75 and 67.85 US Dollars, with a market cap of 10.2 billion dollars.

The financial statements presented below for the Year Ending December 31, 2011 have been prepared using US GAAP. JAL's controller, Mercedes, would like to see the effect of using IFRS on the statement of cash Flows. The company would like to adapt IFRS by as early as next year as it is considering a new stock issue in Costa Rica, which requires IFRS compliance. You have been assigned the task of converting this cash flow financial statement from US GAAP to IFRS. 


\section{AXE CORP. \\ Cash Flow Statement (Direct method) under US GAAP 1/1/2011-12/31/2011}

Cash Flow From Operations

Cash Collections from Sales $\$ 266,000$

Cash paid to Suppliers $\quad(183,000)$

Cash paid for Operating Expenses $\quad(29,000)$

Cash paid for Interest Expense $\quad(4,000)$

Cash paid for Income Taxes $\quad \underline{(9,000)}$

Cash Flow Provided from Operating Activities $\quad 41,000$

\section{Cash Flow from Investing}

Purchase of Equipment

\section{Cash Flow from Financing Activities}

Cash Dividends paid

Net Increase in Cash for the Year $2011 \quad \frac{(3,000)}{25,000}$

Beginning Cash Balance $\underline{28,000}$

Ending Cash balance 12/31/2011 $\$ \underline{\$ 53,000}$

\section{ADDITIONAL INFORMATION}

1. AXE Corp. uses the LIFO method to account for its inventory. The LIFO reserve was $\$ 15,000$ at the beginning of the year and $\$ 19,000$ as of year-end. The effective tax rate for JAL is 25 percent. The company pays all tax liabilities when accrued.

2. Management has established that there is an increase in the Fair market value of Property, Plant and Equipment as of $12 / 31 / 11$ of $\$ 6,000$ above book value.

3. In 2011 , the company spent $\$ 4,000$ on internally feasible development costs, which relates to their pipeline of pharmaceutical drugs.

4. AXE leased specialized machinery manufactured by the lessor, Jones Corp. The lease term is for 3 years with a lease payment made to lessor in the amount of $\$ 5,000$. Payment is due on December 31 of each year, with the first payment due on December 31, 2011. At the end of the lease term, ownership reverts back to lessor. There is no option to buy the equipment.

a. The estimated useful life of the lease is 54 months; 4 and $1 / 2$ years.

b. The fair market value of the equipment is $\$ 15,000$.

c. The interest rate implicit in the lease is 6 percent, and this is known to the lessee, Axe.

d. The incremental borrowing rate of Axe is 7 percent.

e. This lease is treated as an operating lease under US GAAP, and the US GAAP prepared cash flow statement reflects this.

f. Under IFRS, this lease is treated as a capital/financing lease.

5. Assume that AXE has elected to treat interest expense as a cash flow from operations activity, thereby being consistent with the US GAAP prepared statement.

\section{REQUIRED}

1. For items 1-4, identify whether there will be a change in cash flow under IFRS, a reclassification of cash flows, or no effect on cash flow.

2. For items $1-4$, identify where applicable, the reclassification of cash flow among operating, investing and financing activities.

3. Make the necessary changes on the worksheet presented.

4. Prepare an IFRS Compliance Cash Flow Statement for the period 1/1/11 to 12/31/11

5. What other differences exist between US GAAP and IFRS Cash Flow presentation. 


\section{RECOMMENDED SOLUTIONS}

\section{Solutions 1 and 2}

1. IFRS disallows the use of LIFO as an acceptable accounting method. LIFO is allowed under US GAAP, and if used for financial reporting purposes, has to be used for tax purposes: known as the conformity rule. In this case, IFRS will require the use of FIFO and the differential between the cost of goods sold and pre-tax total between LIFO and FIFO will equal the difference in the beginning and the end of year LIFO Reserve. This amount is $\$ 19,000$ less $\$ 15,000$, which equals an increase in pre-tax income under FIFO, by virtue of a higher ending inventory total and lower cost of goods sold amount of $\$ 4,000$. At a tax rate of 25 percent, this amounts to a greater cash tax payment under FIFO of $\$ 1,000$. This will cause a decrease in cash flow under IFRS by virtue of FIFO use. Cash will be reduced by $\$ 1,000$ to $\$ 52,000$.

2. The increase in the carrying amount of Property, Plant and Equipment which is allowable under IFRS and precluded under US GAAP, has no effect on cash flows. It increases comprehensive income on the balance Sheet by $\$ 6,000$.

3. The development costs are capitalized under IFRS, if such costs are traceable and if deemed feasible. Under US GAAP, such costs are expensed when incurred. As such, the $\$ 4,000$ is reclassified under IFRS as a cash payment for Investing Activities, from cash paid from operating activities under US GAAP.

4. A reclassification from operating lease, which treats the rent payment as an operating expense; a cash payment for operating activities, to a capital / financing lease, will result in the purchase of an asset and an incurrence of a liability in the same amount, calculated by discounting the minimum lease payments using the lower implicit rate of the lease or the lessee's incremental borrowing rate. The payment of the lease obligation will thus result as a cash payment for financing activities; which includes a payment of the minimum lease obligation and an interest payment. The amortization table is presented below:

Assuming a capital/financing lease, the amortization table is as follows:

$\begin{array}{ccccc}\text { Year } & \text { Payment } & \text { Interest-6\% } & \text { Principal } & \text { Min. Lease Obligation-Payable \$13,365 } \\ 1 & \$ 5,000 & 802 & 4,198 & 9,167 \\ 2 & 5,000 & 550 & 4,450 & 4,717 \\ 3 & 5,000 & 283 & 4,717 & 0 \\ \text { Totals } & \mathbf{1 5 , 0 0 0} & \mathbf{1 , 6 3 5} & \mathbf{1 3 , 3 6 5} & \text { N/A }\end{array}$




\section{Effects on the Cash Flow Statement}

A: In the year of inception, US GAAP treats the $\$ 5,000$ rent expense as an operating lease payment; a cash outflow from continuing Operations as an Operating expense on the income statement.

Under IFRS, the financing/ capital lease is treated as a purchase of Property, Plant and Equipment and Capitalized on the balance Sheet as such in the amount of $\$ 13,365$, with a corresponding liability in this amount. The effect of the cash flow statement is the payment of the $\$ 5,000$ results in a cash payment of the minimum lease obligation-a cash outflow from Financing Activities in the amount of $\$ 4,198$, and an interest payment -a cash outflow from Financing activities or Operating Activities for $\$ 802$; keeping the same total amount payment of $\$ 5,000$.

B: Subsequent to Year of Inception-years 2 and 3 of lease payments

US GAAP: The $\$ 5,000$ annual Lease payment is treated as a rent expense; a cash outflow from Continuing Operations as an Operating expense.

IFRS: The \$5,000 lease payment is treated as an interest expense payment and a reduction in the liability -Minimum lease obligation Under Financing/ Capital Lease, in the amounts enumerated above per year 1, 2 and 3 calculations. The interest expense is treated either as a cash Outflow from Continuing Operations or a financing activity payment, and the minimum lease obligation payment is treated as a cash outflow from financing activities.

\section{The Resulting Cash Flow Effect Under IFRS}

There will be a decrease in cash flow under IFRS by virtue of FIFO use. Cash will be reduced by 1,000 to $\$ 52,000$.

Solution 3

AXE CORP.

Cash Flow Statement (Direct Method) US GAAP to IFRS Adjustments and Reconciliation 1/1/2011-12/31/2011

\section{Cash Flow from Operations \\ Cash Collections from Sales \\ Cash paid to Suppliers \\ Cash paid for Operating Expenses \\ Cash paid for Interest Expense \\ Cash paid for Income Taxes \\ Cash Flow Provided from Operating Activities}

\section{Cash Flow from Investing}

Purchase of Equipment and Development Costs

Cash Flow from Investing Activities

\section{Cash Flow from Financing Activities}

Cash Dividends paid

Payment of Minimum Lease Obligation Liability

Cash Flow From Financing Activities

Net Increase in Cash for the Year 2011

Balance

Cash balance 12/31/2011

\section{US GAAP}

$\$ 276,000$

$(183,000)$

$(39,000)$

$(4,000)$

$(9,000)$

41,000

$\underline{(13,000)}$

$(13,000)$

(3) $(4,000)$

(3) $4,000+$ (4) 5,000

(4) $(802)$

(1) $(\mathbf{1 , 0 0 0 )}$

ADJUSTMENTS

IFRS Cash Flow

$(3,000)$

25,000

28,000

$\$ \underline{53,000}$
7,198

276,000

$(183,000)$

$(10,000)$

48,198

$(17,000)$

$(17,000)$

$(3,000)$

$\begin{array}{lr}(4,198) & (7,198) \\ , 000) & 24,000 \text { Beginning Cash }\end{array}$

28,000

$\$ 52,000$ 
Note: (1) The decrease of $\$ \mathbf{1 , 0 0 0}$ cash is a result of higher taxes paid by virtue of additional income of $\$ 4,000$, by the use of FIFO-as LIFO is not acceptable under IFRS. (25 percent tax rate time's $\$ 4,000$ results in $\$ 1,000$ of additional tax). (3) The development cost has been reclassified from operating expense to an investing activity-as the $\$ 4,000$ represents the purchase of an intangible asset. (4) The $\$ 5,000$ has been reclassified as a result of operating to capital/financing lease treatment under IFRS

Solution 4: IFRS Prepared Cash Flow Statement

\section{AXE CORP. \\ Cash Flow Statement (Direct Method): IFRS Prepared Cash Flow From Operations}

Cash Collections from Sales

Cash paid for Operating Expenses

Cash paid for Interest Expense

Cash paid for Income Taxes

Cash Flow Provided from Operating Activities

\section{Cash Flow From Investing}

Purchase of Equipment and Development Costs

Cash Flow from Investing Activities

\section{Cash Flow From Financing Activities}

Payment of Minimum Lease Obligation Liability

Cash Flow From Financing Activities

Net Increase in Cash for the Year 2011

Beginning Cash Balance

Ending Cash balance 12/31/2011

$$
\begin{array}{r}
\$ 276,000 \\
(30,000) \\
(4,802) \\
(10,000) \\
\hline 48,198
\end{array}
$$

$\underline{(17,000)}$

$(17,000)$

$(7,198)$

24,000

$\underline{28,000}$

$\$ \underline{52,000}$

Solution 5: Other Differences between US GAAP and IFRS Cash Flow Statement Classifications:

Interest Expense is treated either as a cash flow from operations or a cash flow from financing for IFRS purposes. For US GAAP, interest expense is a cash outflow from continuing operations. Additionally, Interest Revenue and Dividend Revenue under IFRS, is treated either as a cash flow from operations or a cash flow from investing activity, whereas under US GAAP, these items are treated as cash inflows from operating activities.

\section{CONCLUSION}

IFRS is the future of worldwide financial reporting and should be included as a major part of any accounting and/or business curriculum in the US, as well as the rest of the world. This case illustrates a situation where a Cash Flow Statement is prepared using US GAAP as a basis and converting to IFRS for comparison purposes. In this case study IFRS rules are discussed, and key Cash Flow similarities and differences between US GAAP and IFRS are addressed. The differences between US GAAP and IFRS can lead to significant reporting of cash flows, as well as different cash totals, as illustrated in this case.

\section{AUTHOR INFORMATION}

Peter Harris is a Professor and Chair of the Accounting and Finance department at the New York Institute of Technology. Previously, he has worked for Ernst and Young LLP. He is an author of over 50 refereed journal articles and over 140 intellectual contributions. He can be reached at pharris@nyit.edu. 


\section{REFERENCES}

International Financial Accounting Standards (IFRS). IAS numbers: 2, 3, 5, 17, 36, 37, 38, 39.

U.S Generally Accepted Accounting Principles (US GAAP). FASB 13, 95, ASC Numbers: 320, 330, 360, $410,985$. 